\title{
Mechanisms of fluorine-induced separation of mass interference dur- ing TOF-SIMS analysis
}

\author{
Agnieszka Priebe ${ }^{1, *}$, Emese Huszar ${ }^{1,2}$, Marek Nowicki ${ }^{3,4}$, Laszlo Pethö ${ }^{1}$ and Johann \\ Michler ${ }^{1}$
}

'Empa, Swiss Federal Laboratories for Materials Science and Technology, Laboratory for Mechanics of Materials and Nanostructures, Feuerwerkerstrasse 39, $\mathrm{CH}-3602$ Thun, Switzerland

${ }^{2}$ Laboratory for Nanometallurgy, Department of Materials, ETH Zurich, Vladimir-Prelog-Weg 5, 8093, Zurich, Switzerland

${ }^{3}$ Center for Advanced Technology, Adam Mickiewicz University, Uniwersytetu Poznańskiego 1o, 61-614 Poznań, Poland

4Faculty of Materials Engineering and Technical Physics, Poznan University of Technology, 6o-965 Poznań, Poland *Corresponding author: agnieszka.priebe@empa.ch

\section{TABLE OF CONTENT}

Table S1. PVD deposition parameters of $\mathrm{Zr}$, Mo and Ag thin films... S-2

Table S2. PVD deposition parameters of $\mathrm{AgMo} / \mathrm{Al}_{2} \mathrm{O}_{3} / \mathrm{ZrMo} / \mathrm{Al}_{2} \mathrm{O}_{3} / \mathrm{ZrAg} / \mathrm{Al}_{2} \mathrm{O}_{3} / \mathrm{Zr}$ multilayer sample. S-2

Table S3: ALD deposition parameters of $\mathrm{AgMo} / \mathrm{Al}_{2} \mathrm{O}_{3} / \mathrm{ZrMo} / \mathrm{Al}_{2} \mathrm{O}_{3} / \mathrm{ZrAg} / \mathrm{Al}_{2} \mathrm{O}_{3} / \mathrm{Zr}$ multilayer sample...... S-2

Figure S1. Graphical representation of potential mass interference variants between different metal isotopes, their hydrides and dihydrides.

Table $\mathrm{S}_{4}$. Natural isotope abundance of $\mathrm{Zr}$, Mo and Ag.

Figure S2. SEM images of mechanically obtained sample cross-sections..

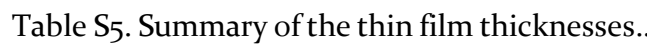
S-4

Table S6: Summary of the results conducted on metal thin films.

Figure $\mathrm{S}_{3}$. Recognition of mass interference. S-4

Figure $\mathrm{S}_{4}$. SEM cross-sectional image of $\mathrm{AgMo} / \mathrm{Al}_{2} \mathrm{O}_{3} / \mathrm{ZrMo} / \mathrm{Al}_{2} \mathrm{O}_{3} / \mathrm{ZrAg} / \mathrm{Al}_{2} \mathrm{O}_{3} / \mathrm{Zr}$.

Figure $\mathrm{S}_{5}$. The TOF-SIMS signals depth profiles measured at $m / q=27$ and $m / q=28$, corresponding to ${ }^{27} \mathrm{Al}^{+}$and ${ }^{28} \mathrm{Si}^{+}$

Figure S6. Part of $\mathrm{AgMo} / \mathrm{Al}_{2} \mathrm{O}_{3} / \mathrm{ZrMo} / \mathrm{Al}_{2} \mathrm{O}_{3} / \mathrm{ZrAg} / \mathrm{Al}_{2} \mathrm{O}_{3} / \mathrm{Zr}$ mass spectrum corresponding to Al- and Si-containing ions

Figure $\mathrm{S}_{7}$. Comparison of mass spectra obtained for $\mathrm{AgMo} / \mathrm{Al}_{2} \mathrm{O}_{3} / \mathrm{ZrMo} / \mathrm{Al}_{2} \mathrm{O}_{3} / \mathrm{ZrAg} / \mathrm{Al}_{2} \mathrm{O}_{3} / \mathrm{Zr}$ under standard vacuum conditions and in the presence of fluorine gas.

Figure S8. TOF-SIMS depth profiles of signals at $\mathrm{m} / q=107$ and 109, corresponding to ${ }^{107} \mathrm{Ag}^{+} \mathrm{and}^{109} \mathrm{Ag}^{+}$. S-7 Figure S9. Depth profiles of $\mathrm{AgMo} / \mathrm{Al}_{2} \mathrm{O}_{3} / \mathrm{ZrMo} / \mathrm{Al}_{2} \mathrm{O}_{3} / \mathrm{ZrAg} / \mathrm{Al}_{2} \mathrm{O}_{3} / \mathrm{Zr}$. S-7 Figure S1o. Normalized to 1 depth profiles of $\mathrm{AgMo} / \mathrm{Al}_{2} \mathrm{O}_{3} / \mathrm{ZrMo} / \mathrm{Al}_{2} \mathrm{O}_{3} / \mathrm{ZrAg} / \mathrm{Al}_{2} \mathrm{O}_{3} / \mathrm{Zr}$. S-8 
Table S1. PVD deposition parameters of $\mathrm{Zr}$, Mo and Ag thin films.

\begin{tabular}{|l|l|l|l|l|l|l|l|}
\hline Layer & $\begin{array}{l}\text { Power } \\
\text { mode }\end{array}$ & $\begin{array}{l}\text { Plasma power } \\
{[\mathrm{W}]}\end{array}$ & $\begin{array}{l}\text { Plasma current } \\
{[\mathrm{mA}]}\end{array}$ & $\begin{array}{l}\text { Deposition time } \\
{[\mathrm{s}]}\end{array}$ & $\begin{array}{l}\text { Base pressure } \\
{[\mathrm{mbar}]}\end{array}$ & $\begin{array}{l}\text { Process pressure } \\
{[\mathrm{mbar}]}\end{array}$ & $\begin{array}{l}\text { Argon flow } \\
{[\mathrm{sccm}]}\end{array}$ \\
\hline $\mathrm{Zr}$ & $\mathrm{DC}$ & 73 & 200 & 1320 & $4.7 \times 10^{-7}$ & $5.2 \times 10^{-3}$ & 35 \\
\hline $\mathrm{Mo}$ & $\mathrm{DC}$ & 72 & 200 & 1760 & $9.0 \times 10^{-7}$ & $5.0 \times 10^{-3}$ & 20 \\
\hline $\mathrm{Ag}$ & $\mathrm{DC}$ & 111 & 200 & 582 & $5.3 \times 10^{-7}$ & $5.0 \times 10^{-3}$ & 20 \\
\hline
\end{tabular}

Table S2. PVD deposition parameters of $\mathrm{AgMo} / \mathrm{Al}_{2} \mathrm{O}_{3} / \mathrm{ZrMo} / \mathrm{Al}_{2} \mathrm{O}_{3} / \mathrm{ZrAg} / \mathrm{Al}_{2} \mathrm{O}_{3} / \mathrm{Zr}$ multilayer sample.

\begin{tabular}{|c|c|c|c|c|c|c|c|}
\hline \multicolumn{2}{|l|}{ Layer } & $\begin{array}{l}\text { Plasma power } \\
{[\mathrm{W}]}\end{array}$ & $\begin{array}{l}\text { Plasma current } \\
{[\mathrm{mA}]}\end{array}$ & $\begin{array}{l}\text { Deposition } \\
\text { time }[\mathrm{s}]\end{array}$ & $\begin{array}{l}\text { Base pressure } \\
{[\mathrm{mbar}]}\end{array}$ & $\begin{array}{l}\text { Process pressure } \\
{[\mathrm{mbar}]}\end{array}$ & $\begin{array}{l}\text { Argon flow } \\
{[\mathrm{sccm}]}\end{array}$ \\
\hline \multirow{2}{*}{ AgMo } & $\mathrm{Ag}$ & 35 & 80 & \multirow{2}{*}{701} & \multirow{2}{*}{$1.6 \times 10^{-8}$} & \multirow{2}{*}{$5.0 \times 10^{-3}$} & \multirow{2}{*}{35} \\
\hline & Mo & 86 & 250 & & & & \\
\hline \multirow{2}{*}{ ZrMo } & $\mathrm{Zr}$ & 93 & 250 & \multirow{2}{*}{655} & \multirow{2}{*}{$2.7 \times 10^{-7}$} & \multirow{2}{*}{$5.0 \times 10^{-3}$} & \multirow{2}{*}{35} \\
\hline & Mo & 74 & 220 & & & & \\
\hline \multirow{2}{*}{$\mathrm{ZrAg}$} & $\mathrm{Zr}$ & 94 & 250 & \multirow{2}{*}{618} & \multirow{2}{*}{$2.3 \times 10^{-7}$} & \multirow{2}{*}{$5.0 \times 10^{-3}$} & \multirow{2}{*}{35} \\
\hline & $\mathrm{Ag}$ & 33 & 80 & & & & \\
\hline \multicolumn{2}{|l|}{$\mathrm{Zr}$} & 72 & 200 & 1322 & $2.4 \times 10^{-7}$ & $5.1 \times 10^{-3}$ & 35 \\
\hline
\end{tabular}

Table $\mathrm{S}_{3}$ : ALD deposition parameters of $\mathrm{AgMo} / \mathrm{Al}_{2} \mathrm{O}_{3} / \mathrm{ZrMo} / \mathrm{Al}_{2} \mathrm{O}_{3} / \mathrm{ZrAg} / \mathrm{Al}_{2} \mathrm{O}_{3} / \mathrm{Zr}$ multilayer sample. 42 cycles were conducted to obtain $5 \mathrm{~nm} \mathrm{Al}_{2} \mathrm{O}_{3}$ thin films.

\begin{tabular}{|c|c|c|c|c|c|}
\hline \multicolumn{4}{|l|}{ Precursor } & \multirow{3}{*}{$\begin{array}{l}\text { Substrate tem- } \\
\text { perature }\left[{ }^{\circ} \mathrm{C}\right]\end{array}$} & \multirow{3}{*}{$\begin{array}{l}\text { Argon flow } \\
{[\mathrm{sccm}]}\end{array}$} \\
\hline \multicolumn{2}{|l|}{$\mathrm{H}_{2} \mathrm{O}$} & \multicolumn{2}{|l|}{$\mathrm{Al}\left(\mathrm{CH}_{3}\right)_{3}$} & & \\
\hline $\begin{array}{l}\text { Precursor tempera- } \\
\text { ture }\left[{ }^{\circ} \mathrm{C}\right]\end{array}$ & Pulse time [ms] & Precursor temperature $\left[{ }^{\circ} \mathrm{C}\right]$ & $\begin{array}{l}\text { Pulse time } \\
{[\mathrm{ms}]}\end{array}$ & & \\
\hline 45 & 0.05 & 72 & 0.05 & 120 & 50 \\
\hline
\end{tabular}




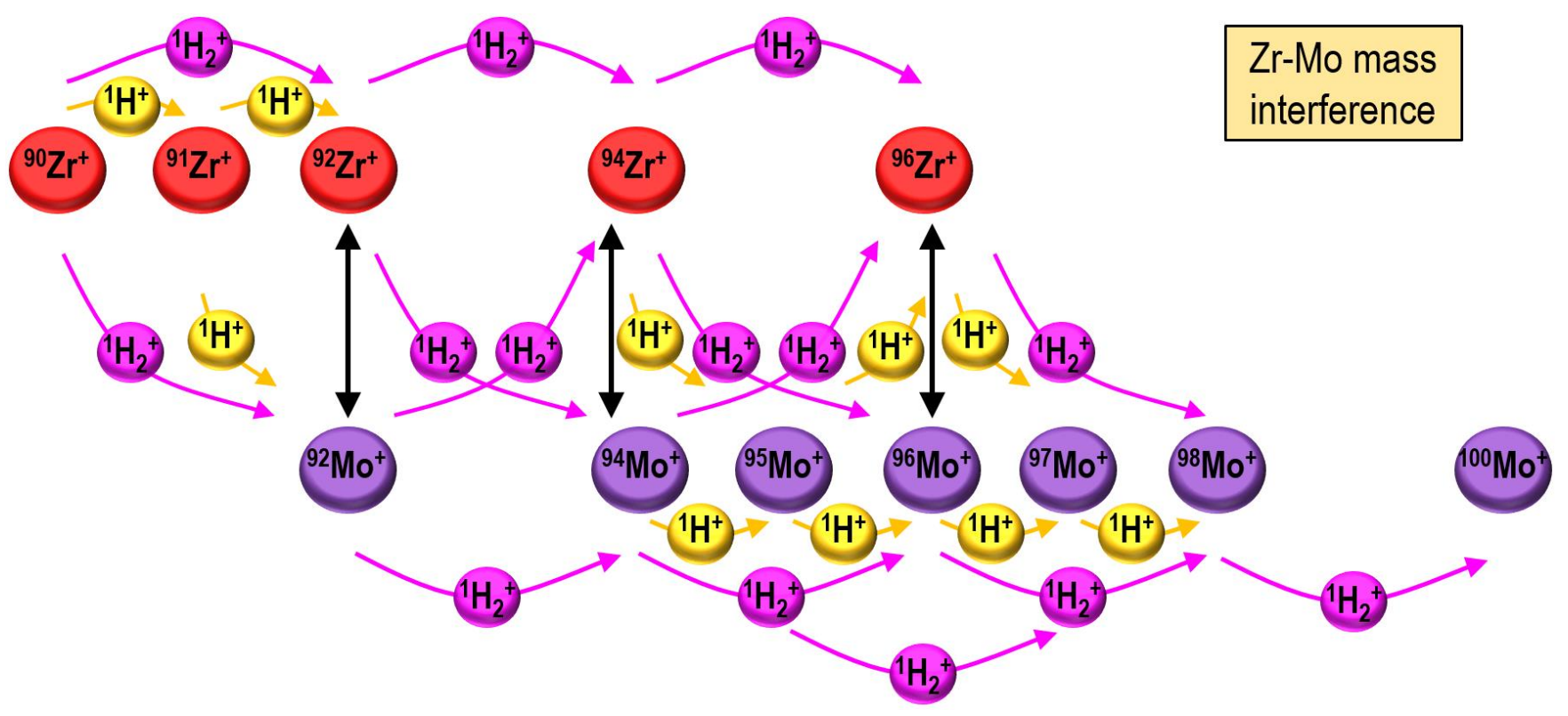

Figure S1. Graphical representation of potential mass interference variants between different metal isotopes (isobaric interference, $1^{\text {st }}$ order mass interference), their hydrides ( $2^{\text {nd }}$ order mass interference) and dihydrides ( $3^{\text {rd }}$ order mass interference) in the case of a system containing $\mathrm{Zr}$ (given in red) and Mo (given in violet). ${ }^{1} \mathrm{H}^{+}$ions, which contribute to $\mathrm{ZrH}$ and $\mathrm{MoH}$ ions formation, are shown in yellow. ${ }^{1} \mathrm{H}_{2}{ }^{+}$ions, which contribute to $\mathrm{ZrH}_{2}$ and $\mathrm{MoH}_{2}$ ions formation, are given in pink. The arrows indicate the direction of ions' influence on the signal measured at a given $m / q$. For example, the signal measured at $m / q=92$, corresponding to ${ }^{92} \mathrm{Zr}^{+}$ions, is a sum of signals coming from ${ }^{92} \mathrm{Zr}^{+},{ }^{92} \mathrm{Mo}^{+},{ }^{91} \mathrm{Zr}^{1} \mathrm{H}^{+},{ }^{9} \mathrm{Zr}^{1} \mathrm{H}_{2}{ }^{+}$secondary ions.

Table $\mathrm{S}_{4}$. Natural isotope abundance of $\mathrm{Zr}$, Mo and Ag. Source: TOF-SIMS Explorer version 1.4.4.o software from TOFWERK.

\begin{tabular}{|l|l|l|l|l|l|l|l|l|l|l|l|}
\hline$m / q$ & 90 & 91 & 92 & 94 & 95 & 96 & 97 & 98 & 100 & 107 & 109 \\
\hline $\mathrm{Zr}$ & $51.5 \%$ & $11.2 \%$ & $17.2 \%$ & $17.4 \%$ & & $2.8 \%$ & & & & & \\
\hline $\mathrm{Mo}$ & & & $14.8 \%$ & $9.2 \%$ & $15.9 \%$ & $16.7 \%$ & $9.6 \%$ & $24.2 \%$ & $9.7 \%$ & & \\
\hline $\mathrm{Ag}$ & & & & & & & & & & $51.8 \%$ & $48.2 \%$ \\
\hline
\end{tabular}
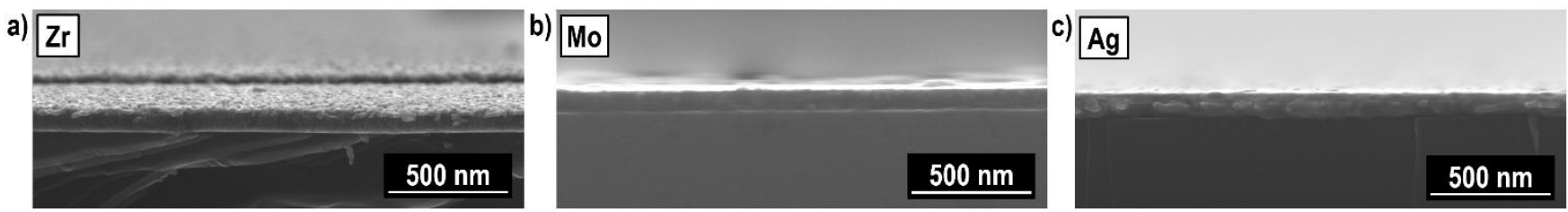

Figure S2. SEM images of mechanically obtained sample cross-sections. The Si substrate is at the bottom. The think film thickness of $h_{Z r}=81 \pm 3 \mathrm{~nm}, h_{M o}=88 \pm 4 \mathrm{~nm}, h_{A g}=100 \pm 2 \mathrm{~nm}$ were measured in the case of $\mathrm{Zr}$ (a), Mo (b) and Ag (c), respectively. 
Table $S_{5}$. Summary of the thin film thicknesses, $h$, measured on the samples' cross-sections using SEM (Figures S2) and calculated sputtering rates.

\begin{tabular}{|l|l|l|l|}
\hline \multirow{2}{*}{ Sample } & \multirow{2}{*}{$h[\mathrm{~nm}]$} & \multicolumn{2}{|l|}{ Sputtering rate $[\mathrm{nm} /$ frame] } \\
\cline { 3 - 4 } & & Without gas & With fluorine gas \\
\hline $\mathrm{Zr}$ & $81 \pm 3$ & $1.8 \pm 0.2$ & $2.8 \pm 0.2$ \\
\hline $\mathrm{Mo}$ & $88 \pm 4$ & $3.3 \pm 0.6$ & $5.9 \pm 0.7$ \\
\hline $\mathrm{Ag}$ & $100 \pm 2$ & $4.3 \pm 0.7$ & $14 \pm 3$ \\
\hline
\end{tabular}

Table S6: Summary of the results conducted on metal thin films: $t_{\text {interface }}$ denotes the time of reaching the interface between the metal thin film and the $S i$ substrate, $S_{\text {total }}$ is the total secondary ion signal of a given isotope, the indexes reference and fluorine refer to the measurements conducted without and with fluorine gas. The given values are the averages of three measurements.

\begin{tabular}{|l|l|l|l|l|l|l|}
\hline \multirow{2}{*}{ Isotope } & \multicolumn{2}{|l|}{ Ga beam current [pA] } & \multicolumn{2}{l|}{ Moment of reaching the interface [frames] } & \multicolumn{2}{l|}{ Total integrated current [counts/pixel/pA] } \\
\cline { 2 - 7 } & $I_{\text {reference }}$ & $I_{\text {fluoriene }}$ & $t_{\text {interface_reference }}$ & $t_{\text {interface_fluorine }}$ & $S_{\text {total_reference }}$ & $S_{\text {total_fluorine }}$ \\
\hline${ }^{9} \mathrm{Zr}^{+}$ & 117.3 & 119 & $46 \pm 2$ & $29 \pm 1$ & $(4.0 \pm 0.2) \times 10^{-4}$ & $(1.50 \pm 0.02) \times 10^{-3}$ \\
\hline${ }^{98} \mathrm{Mo}^{+}$ & 118 & 119.3 & $27 \pm 3$ & $15 \pm 1$ & $(3.6 \pm 0.2) \times 10^{-5}$ & $(1.61 \pm 0.06) \times 10^{-3}$ \\
\hline${ }^{107} \mathrm{Ag}^{+}$ & 118 & 119.3 & $23 \pm 3$ & $7 \pm 1$ & $(7 \pm 2) \times 10^{-6}$ & $(3.3 \pm 0.3) \times 10^{-3}$ \\
\hline
\end{tabular}

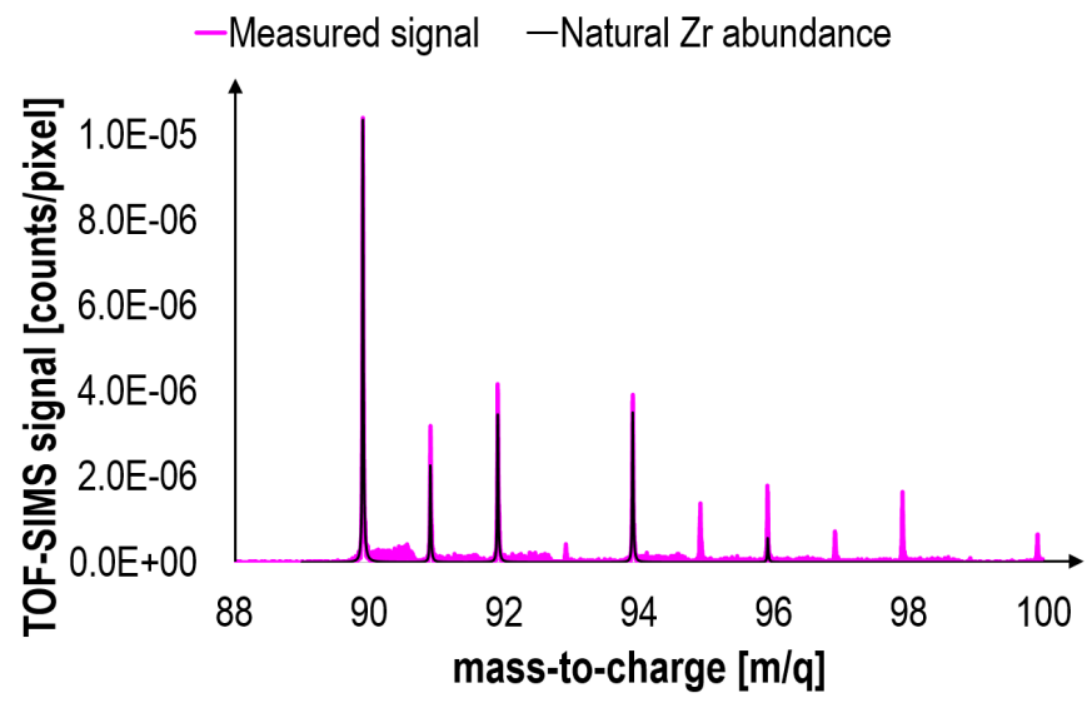

Figure $\mathrm{S}_{3}$. Recognition of mass interference. The measured $\mathrm{Zr}$ signal (pink line) in $\mathrm{AgMo} / \mathrm{Al}_{2} \mathrm{O}_{3} / \mathrm{ZrMo} / \mathrm{Al}_{2} \mathrm{O}_{3} / \mathrm{ZrAg} / \mathrm{Al}_{2} \mathrm{O}_{3} / \mathrm{Zr}$ sample is fitted to the $\mathrm{Zr}$ natural isotope abundance (black line). The difference between the two lines suggests the contribution of other ions (Mo in this case) to the total measured signal. Data acquired under standard vacuum conditions. 


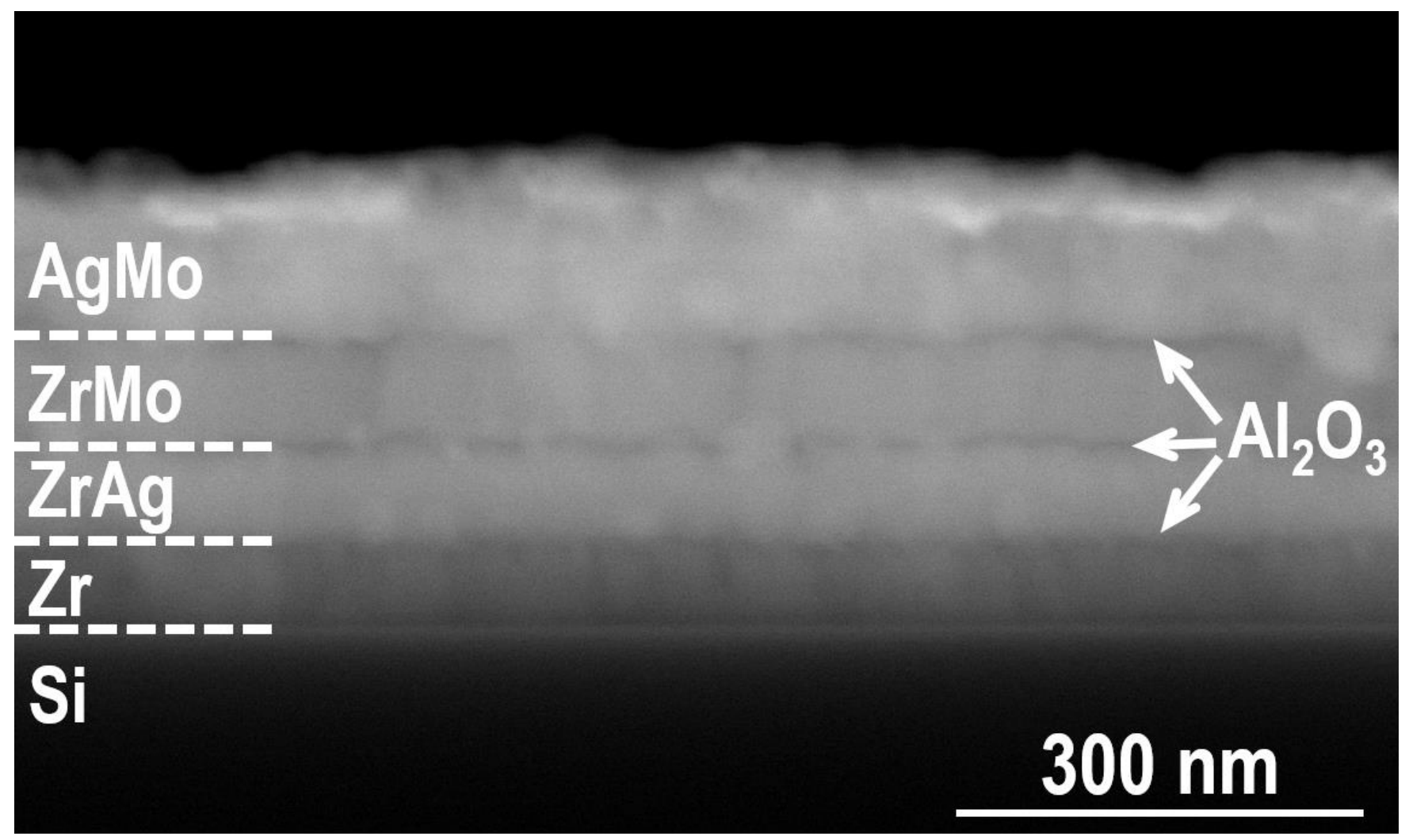

Figure $\mathrm{S}_{4}$. The SEM image of mechanically obtained $\mathrm{AgMo} / \mathrm{Al}_{2} \mathrm{O}_{3} / \mathrm{ZrMo} / \mathrm{Al}_{2} \mathrm{O}_{3} / \mathrm{ZrAg} / \mathrm{Al}_{2} \mathrm{O}_{3} / \mathrm{Zr}$ cross-section. The roughness of the PVD-deposited metallic layers was sufficiently low to prevent potential misinterpretation during further analysis of TOF-SIMS depth profiles. All metallic thin films were well-separated and the layer thicknesses in the order of $100 \mathrm{~nm}$ were achieved (i.e. $h_{A g M o}=133 \pm 9 \mathrm{~nm}, h_{Z r M o}=77 \pm 3 \mathrm{~nm}, h_{Z r A g}=69 \pm 4 \mathrm{~nm}$ and $\left.h_{Z r}=61 \pm 2 \mathrm{~nm}\right)$. The ceramic layers were visible as well but they were too shallow to measure their size.

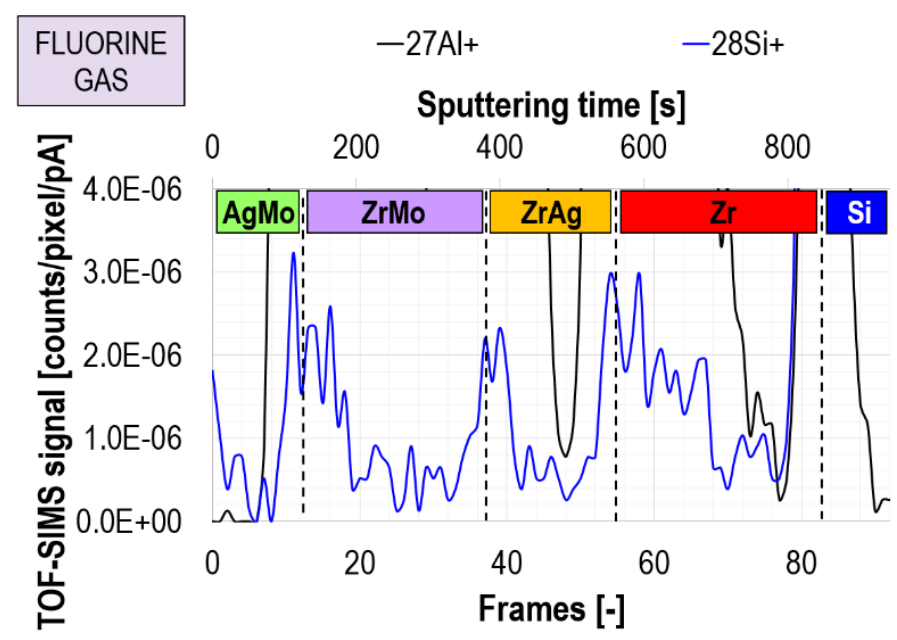

Figure $\mathrm{S}_{5}$. The TOF-SIMS signals depth profiles measured at $m / q=27$ and $m / q=28$, corresponding to ${ }^{27} \mathrm{Al}^{+}$and ${ }^{28} \mathrm{Si}^{+}$. Data obtained during the fluorine gas-assisted measurement. 


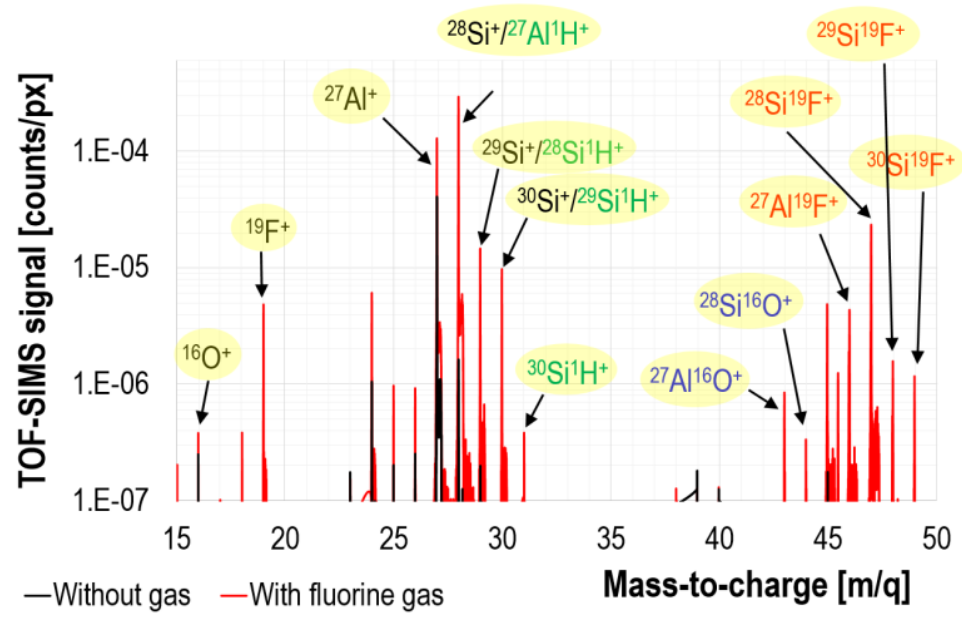

Figure S6. Part of $\mathrm{AgMo} / \mathrm{Al}_{2} \mathrm{O}_{3} / \mathrm{ZrMo} / \mathrm{Al}_{2} \mathrm{O}_{3} / \mathrm{ZrAg} / \mathrm{Al}_{2} \mathrm{O}_{3} / \mathrm{Zr}$ mass spectrum corresponding to Al- and Si-containing ions. Contribution of ${ }^{29} \mathrm{Si}^{16} \mathrm{O}^{+}$and ${ }^{30} \mathrm{Si}^{16} \mathrm{O}^{+}$ions to the signals measured at $m / q=45$ and $m / q=46$ are negligible due to the low contribution of ${ }^{29} \mathrm{Si}$ and ${ }^{30} \mathrm{Si}$ isotopes to the $\mathrm{Si}$ natural isotope abundance (i.e. $92.2 \%{ }^{28} \mathrm{Si}, 4.7 \%{ }^{29} \mathrm{Si}, 3.1 \%{ }^{30} \mathrm{Si}$ ) and relatively low ${ }^{28} \mathrm{Si}^{16} \mathrm{O}^{+}$signal. $\mathrm{Note}$ logarithmic scale.
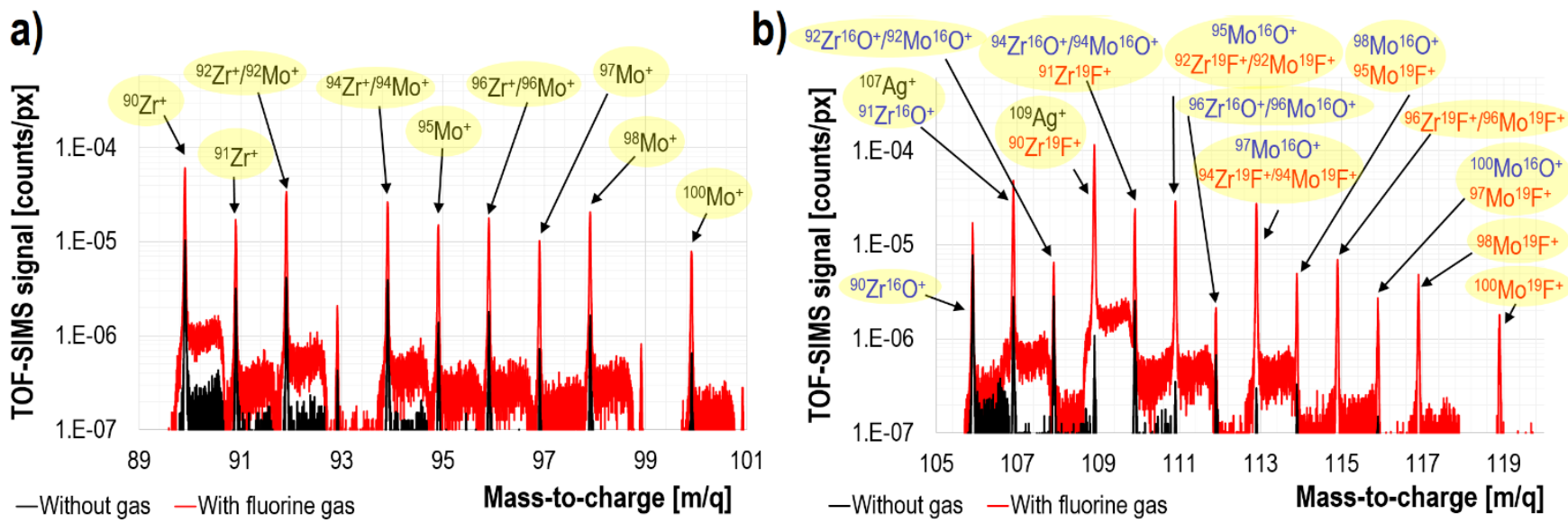

Figure $\mathrm{S}_{7}$. Comparison of mass spectra obtained for $\mathrm{AgMo} / \mathrm{Al}_{2} \mathrm{O}_{3} / \mathrm{ZrMo} / \mathrm{Al}_{2} \mathrm{O}_{3} / \mathrm{ZrAg} / \mathrm{Al}_{2} \mathrm{O}_{3} / \mathrm{Zr}$ under standard vacuum conditions (black lines) and in the presence of fluorine gas (red line). A) a mass spectrum range corresponding to $\mathrm{Zr}$ and Mo ions, b) a mass spectrum range corresponding to $\mathrm{Ag}$ ions as well as $\mathrm{Zr}$ - and Mo- oxides and fluorides. 


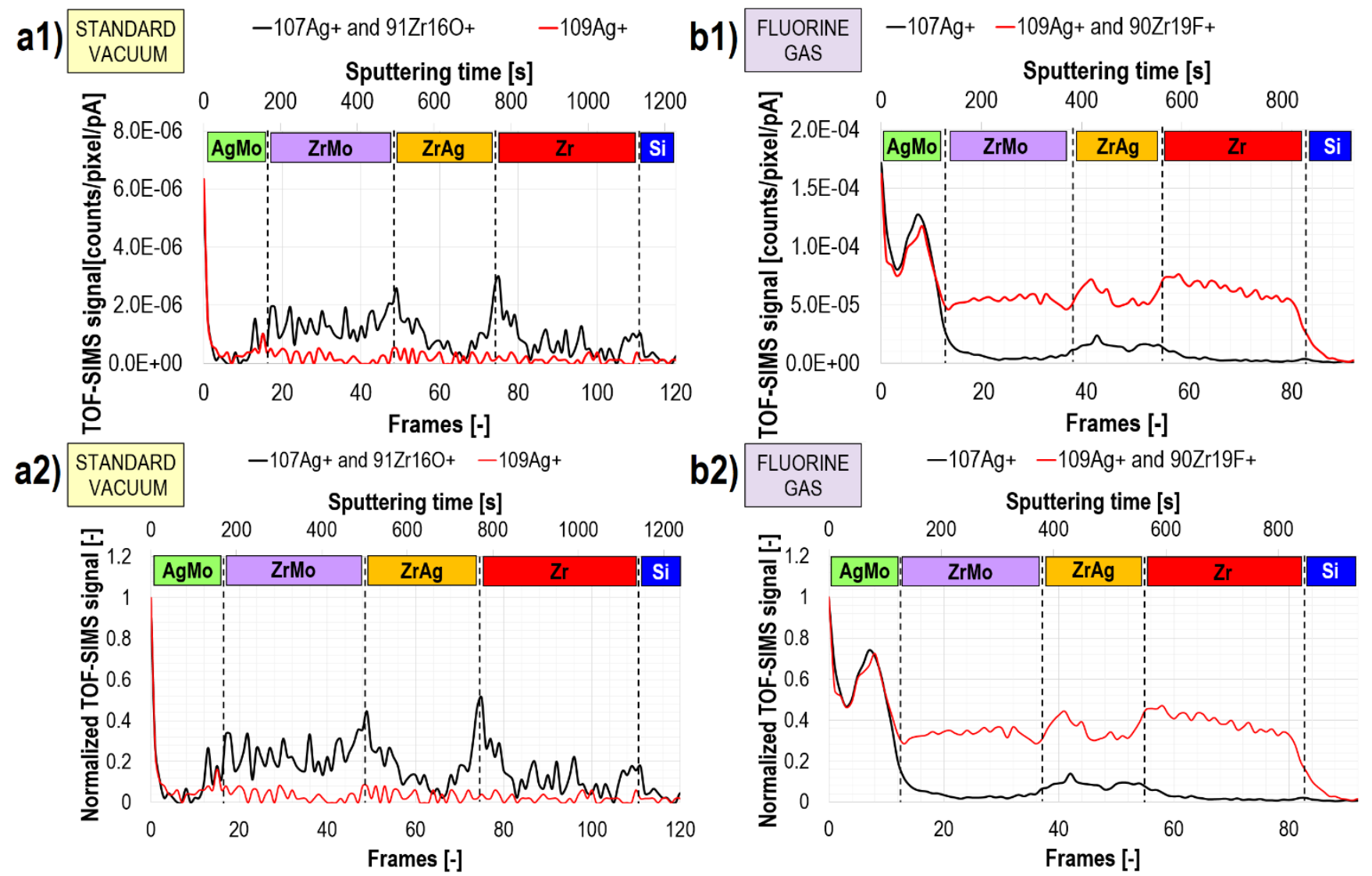

Figure S8. TOF-SIMS depth profiles of signals at $m / q=107$ and 109 , corresponding to ${ }^{107} \mathrm{Ag}^{+} \mathrm{and}^{109} \mathrm{Ag}^{+}$, respectively, measured without (a1 and a2) and with (b1 and b2) fluorine gas. Figures a1 and b2 are given in absolute values, whilst Figures a2 and b2 show values normalized to 1 .
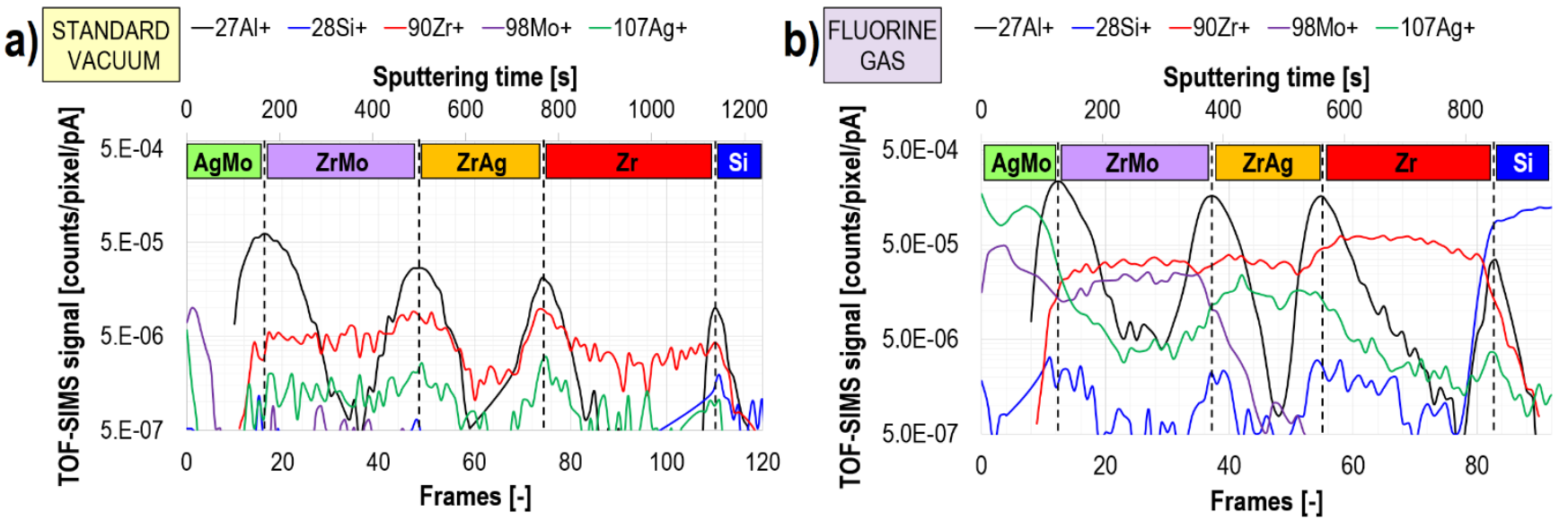

Figure S9. Depth profiles (in logarithmic scale) of $\mathrm{AgMo} / \mathrm{Al}_{2} \mathrm{O}_{3} / \mathrm{ZrMo} / \mathrm{Al}_{2} \mathrm{O}_{3} / \mathrm{ZrAg} / \mathrm{Al}_{2} \mathrm{O}_{3} / \mathrm{Zr}$ multilayer's most prominent isotope signals acquired without (a) and with (b) fluorine gas. Data integration over $5 \mu \mathrm{m} \times 5 \mu \mathrm{m}$ in the $x-y$ plane. 

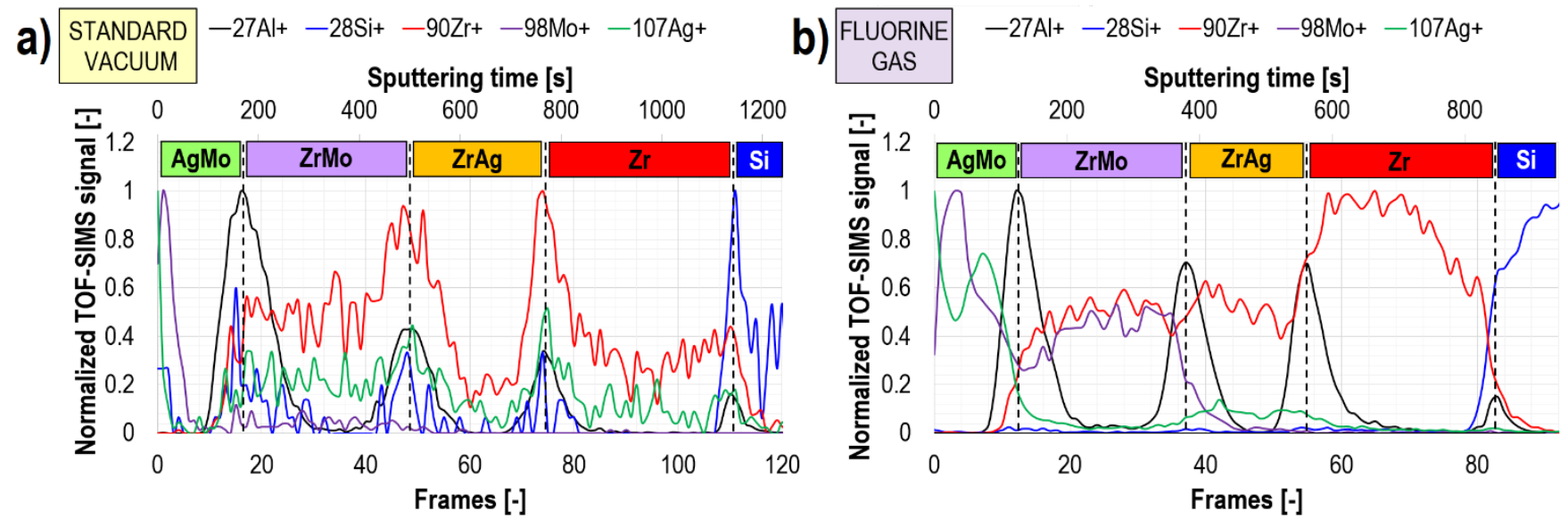

Figure Sio. Normalized to 1 depth profiles of $\mathrm{AgMo} / \mathrm{Al}_{2} \mathrm{O}_{3} / \mathrm{ZrMo} / \mathrm{Al}_{2} \mathrm{O}_{3} / \mathrm{ZrAg} / \mathrm{Al}_{2} \mathrm{O}_{3} / \mathrm{Zr}$ multilayer's most prominent isotope signals acquired without (a) and with (b) fluorine gas. Data integration over $5 \mu \mathrm{m} \times 5 \mu \mathrm{m}$ in the $x$-y plane. Depth profiles with absolute values are given in Figure $\mathrm{S}$. 